\title{
KLINIKINIS ATVEJIS: DIEULAFOY PAŽEIDIMAS
}

\author{
Ilma Vilčinskaitė1, Gintarė Srẻbaliūtė², Martynas Garčauskis² \\ ${ }^{1}$ Klaipédos universitetinè ligoninè, ${ }^{2}$ Lietuvos sveikatos mokslu universiteto Medicinos fakultetas
}

\author{
Raktažodžiai: kraujavimas iš viršutinio virškinamojo \\ trakto, Dieulafoy pažeidimas, angiografija, anemija, hemos-
} tazè.

\begin{abstract}
Santrauka
Dieulafoy pažeidimas (DP) yra 1-2 \% kraujavimo iš viršutinio virškinamojo trakto atvejų priežastis. Dèl šiai patologijai būdingo nepastovaus kraujavimo tiksliai diagnozei nustatyti gali prireikti pakartotinio endoskopinio tyrimo ar net angiografijos. Pristatomas klinikinis atvejis - pacientei lettinès anemijos priežastis nustatyta tik per pakartotini endoskopinị tyrimą, kai pastebėtas aktyvus kraujavimas iš dvylikapirštès žarnos kraujagyslių defekto. Kombinuojant medikamentinį gydymą ir šiuolaikines invazinio kraujavimo stabdymo procedūras, atlikta sèkminga hemostazè.
\end{abstract}

\section{Ivadas}

Kraujavimas iš viršutinio virškinamojo trakto (VVT) - dažnai pasitaikanti ir gyvybei pavojinga būklè. Šios patologijos pasireiškimo dažnis svyruoja nuo 65 iki 134 atvejų 100000 gyventojų [1,2]. Dažniausios kraujavimo iš VVT priežastys yra pepsinès skrandžio ir dvylikapirštės žarnos opos (26-59 \%), erozinis gastritas bei duodenitas (7-28\%), Mallory-Weiss sindromas (7-12\%), ezofagitas (4-12\%) ir piktybiniai navikai (4-6\%). Tik 2-8 \% visų atvejų sudaro kraujagyslinès anomalijos (angiodisplazija, DP, prievarčio kraujagyslių išsiplètimas (GAVE) [3]. Taigi nors kraujagyslinès anomalijos virškinamajame trakte yra santykinai retas reiškinys, jų sukeltas kraujavimas gali būti pavojingas gyvybei, todèl svarbu laiku diagnozuoti ir gydyti šią patologiją.

DP sudaro tik 1-2\% kraujavimų iš VVT, tačiau dèl sudètingos šio sutrikimo diagnostikos tikètina, kad dažnis gali būti didesnis [4]. DP apibrèžiamas kaip anomali, prasiplètusi pogleivio kraujagyslè, kuri per įtrūkimą gleivinèje atsiveria i skrandžio ar žarnos spindį ir neturi pirminio opinio pažeidimo gleivinèje [5,6]. Morfologiškai gleivinès defektas yra 2-5 mm dydžio ir apsuptas sveikos gleivinès. Pažeidimo viduryje pastebima stambi, $1-3 \mathrm{~mm}$ skersmens ir daugiau negu 10 kartų didesnè, nei ịprasta, pogleivio kraujagyslè
$[4,7]$. Histologiškai kraujagyslès morfologija nepakitusi, nėra struktūrinių pokyčių, būdingų aneurizmoms, aterosklerozei, elastinių audinių patologijai ar vaskulitui $[5,8]$. Priežastys, predisponuojančios kraujagyslès atsiverimą ị gleivinę, nèra iki galo aiškios. Vyrauja hipoteze, kad patologinè kraujagyslè savo pulsacija sukelia gleivinejje išeminị stresą ir, mechaniniu būdu plyšus gleivinei, atsiveria ị virškinamajị traktą. Tikètina, jog gleivinès atrofija, pažeidimas dèl NVNU ar alkoholio vartojimo taip pat turi įtakos spontaniniam gleivinès plyšimui DP atveju $[4,6]$.

Dažniausiai (70 \%) DP lokalizuojasi skrandžio gleivinëje, 6-10 cm žemiau gastroezofaginès jungties, ties mažaja skrandžio kreive [6,9]. Dvylikapirštès žarnos pažeidimas sudaro vos $15 \%$ visų atvejų, tai dažniausia ekstragastrinè lokalizacija. Tačiau DP gali būti įvairiose virškinamojo trakto vietose, aprašyti ir keli bronchų pažeidimo atvejai $[4,10]$.

Vyrams DP skrandžio gleivinèje pasireiškia du kartus dažniau nei moterims. Bet esant pažeidimui dvylikapirštejje žarnoje, sąsajos su paciento lytimi nepastebeta [10]. Net $90 \%$ visų sergančiųjų turi šalutinių patologijų ir rizikos veiksnių (širdies ir kraujagyslių ligos, arterinè hipertenzija, lètinès inkstų ligos, cukrinis diabetas, alkoholio vartojimas, rūkymas), nulemiančių DP išsivystymą. Daugiau kaip pusè visų pacientų vartoja NVNU, aspiriną, varfariną, tačiau tiesioginis šių faktorių poveikis DP išsivystymui kol kas nèra irodytas $[4,6]$.

Kliniškai DP dažniausiai pasireiškia melena (44 \%), vèmimu krauju ar ị kavos tirščius panašiu turiniu (30 \%), hematochezija, hipotenzija, blyškumu, bendru silpnumu, anemija. Skirtingai nei esant pepsinems opoms, DP atveju kraujavimas prasideda be skausmų, tačiau ištikus kombinuotai patologijai, galimi dispepsijos reiškiniai, todèl diferencijuoti šiuos susirgimus būtina. Dažniausiai DP sukeltas kraujavimas iš VVT būna masyvus ar intermituojančio pobūdžio, sąlygojantis ūmios ar lètinès posthemoraginès anemijos vystymąsi, geležies deficito atsiradimą ir progresavimą $[4,6,10]$.

Ūmus kraujavimas iš VVT yra gyvybei pavojinga būklè, reikalaujanti greitos ir adekvačios diagnostikos bei neatidèliotino gydymo. Itariant masyvų kraujavimą iš VVT, svarbu užtikrinti pagrindines paciento gyvybines funkcijas 
ir hemodinamikos stabilumą, atlikti laboratorinius kraujo tyrimus, kad būtu ịvertinta paciento sveikatos būklè ir gydymo efektyvumas. Taip pat reikalinga nustatyti kraujo grupę bei sutapatinti kraujo preparatus transfuzijai.

Auksiniu standartu DP diagnostikoje ir gydyme laikomas endoskopinis skrandžio ir dvylikapirštės žarnos tyrimas. Dèl šiai patologijai būdingo nepastovaus kraujavimo dažnai sudètinga aptikti pažeidimo lokalizaciją, todèl tiksliai diagnozei gali prireikti pakartotinès endoskopijos. Atlikus pirminę endoskopiją, DP nustatomas $70 \%$ atvejų. Aktyvaus kraujavimo metu stebimas nedidelis skrandžio, rečiau dvylikapirštès ar plonosios žarnos pažeidimas su atvira, prasiveržiančia kraujagysle. Jei aplink pažeidimą esanti gleivinè nepakitusi, be opinių defektų, galima atmesti opaligę ar malignizaciją. Nepastebejus aktyvaus kraujavimo, pažeidimas per endoskopą matomas kaip spenelio pavidalo normalios gleivinès iškilimas ar hipertrofinè gleivinès raukšlè $[4,6,7,10,11]$. Neinformatyvios fibrogastroduodenoskopijos (FGDS) atveju galimi alternatyvūs diagnostikos metodai: endosonoskopija, kapsulinè endoskopija, scintigrafija su 99m Tc žymètais eritrocitais $[10,12]$.

Nustačius DP lokalizaciją, nedelsiant atliekama hemostazè adrenalino injekcijomis, sklerozantais, termokoaguliacija, hemoklipsais ar kitomis priemonemis [4]. Metodo pasirinkimas priklauso nuo endoskopuotojo technikos ir igūdžių, tačiau yra duomenų, kad efektyvesnès mechaninès hemostazès priemonès [13].

Jei nerastas kraujavimo šaltinis ar nepavyko sustabdyti kraujavimo endoskopiškai, atliekama angiografija. DP atveju stebima kontrastinès medžiagos ekstravazacija. Atliekant angiografiją, taip pat galima imtis embolizacijos, kad būtų sustabdytas kraujavimas. Po šios procedūros išlieka išeminio sienelès pažeidimo rizika. Negavus teigiamo terapinio efekto minimaliai invaziniais gydymo metodais ar kartojantis kraujavimui, gali būti taikomas chirurginis gydymas [10]. Toliau gydant pacientą, skiriami protonų siurblio inhibitoriai, eritrocitų masès transfuzijos, o kliniškai išryškèjusios anemijos atveju skiriami geležies preparatai.

Pakartotinio kraujavimo rizika išlieka iki $40 \%$ atvejų. Tokio kraujavimo tikimybè mažesnè ji stabdant daugiau nei vienu endoskopiniu hemostazès metodu $-3,6 \%$, o pritaikius tik vieną metodą, pakartotinio kraujavimo tikimybe siekia $6,4 \%$. Didžiausia rizika, kad kraujavimas dèl DP kartosis, išlieka iki 30 parų. Plečiantis endoskopijos galimybėms, mirštamumas šios patologijos sumažejo nuo 80 \% iki 8,6 \% $[4,12]$.

Darbo tikslas - pristatyti retai pasitaikančią kraujavimo iš viršutinio virškinamojo trakto priežastį - Dieulafoy pažeidimą.

\section{Klinikinis atvejis}

Dèl maždaug 6 metus stebimos neaiškios kilmès anemijos, pasikartojančios melenos ir bendro silpnumo $2018 \mathrm{~m}$. lapkritị 67 metų paciente planine tvarka stacionarizuota ị gastroenterologijos skyrių, kad būtų ištirtas virškinamasis traktas.

Pacientė prieš dvi savaites jau buvo tirta gastroenterologijos skyriuje dèl įtariamo kraujavimo iš VVT; atlikus FEGDS, rastas paviršinis gastritas, tačiau kraujavimo šaltinio nestebèta. $2017 \mathrm{~m}$. atliktame FKS tyrime patologiniu pokyčių nerasta.

Paciente serga pirmine arterine hipertenzija, cukriniu diabetu ir hipotireoze. Tiriant objektyviai: AKS - 130-80 $\mathrm{mm} \mathrm{Hg}$, ŠSD - 80 k./min., alsavimas plaučiuose vezikulinis, be karkalų, pilvas čiuopiant minkštas, neskausmingas, kojose edemų nèra, oda ir gleivinès blyškios.

Atlikus bendraji kraujo tyrimą, nustatyta izoliuota normocitinè normochrominè anemija: RBC - 1,67 x 10 12 /, HGB - $46 \mathrm{~g} / \mathrm{l}, \mathrm{HCT}-19,5 \%$, RET $\%$ - 11,28 \%, Fe - 4,1 $\mu \mathrm{mol} / \mathrm{l}$, Feritinas - 9,74 $\mu \mathrm{g} / 1, \mathrm{LDH}-132 \mathrm{U} / 1$, kita - n.y. Anemija koreguota eritrocitu masès transfuzijomis. Po 6 EMT hemoglobino koncentracija atstatyta iki $88 \mathrm{~g} / 1$, tačiau po kelių dienų vèl sumažèjo iki $69 \mathrm{~g} / 1$, taikytos pakartotinès transfuzijos. Kad būtų ekskliuduotas piktybinis procesas, atliktas pilvo organų KT tyrimas, nustatyta hepatosplenomegalija. Nepastebėta urostazès, laisvo skysčio pilve, papildomų darinių kasos ar antinksčių projekcijoje.

Pacientè konsultuota hematologo dèl tikètinos posthemoraginès anemijos. Rekomenduota anemijos korekcija eritrocitų masėmis ir geležies preparatais.

Per FKS apžiūrą iki aklosios žarnos tiesiojoje žarnoje rasti 4 polipai, kurių skersmuo siekia $1 \mathrm{~cm}$. Pacientei atlikus FEGDS, stemplèje patologinių pokyčių nerasta, skrandis pripildytas apvirškinto maisto turinio, antralinėje skrandžio dalyje pastebeta $3 \mathrm{~mm}$ skersmens angiodisplazija be aktyvaus kraujavimo. Dvylikapirštejje žarnoje pakitimų nerasta.

Kadangi angiodisplazijos, kaip galimos kraujavimo iš virškinamojo trakto priežasties, nebuvo galima atmesti, planuota defektą koaguliuoti argono plazma endoskopinio tyrimo metu, bet paciente pasijuto blogai, pradejo skųstis progresuojančiu silpnumu ir galvos svaigimu. Atlikus bendraji kraujo tyrimą, rasta iki $64 \mathrm{~g} / 1$ sumažejusi hemoglobino koncentracija, paskirti 2 vienetai eritrocitų masès.

Atlikta pakartotine FEGDS, kuri parode, jog skrandžio pakitimai atitinka anksčiau atliktą FEGDS, tačiau dvylikapirštejje žarnoje rasta šviežio kraujo, be to, stebèti DP būdingi pakitimai - kraujavimas iš kraujagyslès, atsiveriančios ị gleivinę, bet be išopejjimo požymių. Atlikta hemostazè $0,1 \% 20$ $\mathrm{ml}$ adrenalino tirpalu, uždèti 3 titaniniai klipsai, kraujavimas sustabdytas.

Dèl galimo kraujavimo pasikartojimo multidisciplininio 
konsiliumo metu nuspręsta atlikti $a$. mesenterica superior ir truncus coeliacus baseino angiografiją, o ịvykus ekstravazacijai, planuota imtis embolizacijos. Atliekant angiografiją, pastebėta kontrastinès medžiagos ekstravazacija iš a. gastroduodenalis, kraujagyslè embolizuota. Per kontrolinę angiografiją ekstravazacijos požymių nerasta.

Hemoglobino kiekis pacientès kraujyje stabilizavosi. Koreguojant anemiją, per visą gydymo laikotarpi nuo stacionarizavimo buvo sulašinta 11 vienetų EM. Būklei pagerèjus ir nepastebint komplikacijų, paciente 5 parą po embolizacijos išleista iš ligoninès ambulatoriniam gydymuisi. Išrašymo metu bendrajame kraujo tyrime RBC - 3,62 x 10 12/1, HGB - 95 g/1, HCT - 30,8 \%.Rekomenduota vartoti geležies preparatus, kartoti bendrą kraujo tyrimą po 10 dienų, o atsiradus silpnumui, melenai ar kitiems kraujavimo iš VVT požymiams skubiai kreiptis ị gydytoją, kuris nuspręstų, ar reikalinga pakartotine angiografija kraujavimo galimybei ivertinti.

\section{Išvados}

DP yra reta ir gyvybei pavojinga kraujavimo iš viršutinio virškinamojo trakto priežastis, kurią sunku diagnozuoti dèl nepastovaus ir protarpinio kraujavimo. Auksinis diagnostikos standartas - endoskopinis skrandžio ir dvylikapirštės žarnos tyrimas. Dèl DP būdingo nepastovaus kraujavimo dažnai sudètinga aptikti pažeidimo lokalizaciją. Pateiktas klinikinis atvejis parodo, kad aktyvus kraujavimas ir diagnozė buvo nustatyta tik pakartotinio endoskopinio tyrimo metu. Sëkminga hemostazé atlikta kombinuojant medikamentini gydymą ir šiuolaikines invazines kraujavimo stabdymo procedūras: adrenalino tirpalo injekcijas ị gleivinę, defekto užspaudimą titaniniais klipsais, a. gastroduodenalis embolizavimą per angiografijos procedūrą.

Po medikamentinio ir invazinio gydymo pacientès būklè pagerejjo, hemoglobinas stabilizavosi.

\section{Literatūra}

1. Wuerth BA, Rockey DC. Changing epidemiology of upper gastrointestinal hemorrhage in the last decade: a nationwide analysis. Dig Dis Sci 2018;63:1286.

https://doi.org/10.1007/s10620-017-4882-6

2. Siau K, Chapman W, Sharma N, Tripathi D, Iqbal T, Bhala $\mathrm{N}$. Management of acute upper gastrointestinal bleeding: an update for the general physician. J R Coll Physicians Edinb 2017 Sep;47(3):218-230.

https://doi.org/10.4997/JRCPE.2017.303

3. Samuel R, Bilal M, Tayyem O, Guturu P. Evaluation and management of non-variceal upper gastrointestinal bleeding. Dis Mon 2018 Jul;64(7):333-343.

https://doi.org/10.1016/j.disamonth.2018.02.003
4. Baxter M, Aly EH. Dieulafoy's lesion: current trends in diagnosis and management. Ann R Coll Surg Engl 2010;92(7):548-554. https://doi.org/10.1308/003588410X12699663905311

5. Lee YT, Walmsley RS, Leong RW, Sung JJ. Dieulafoy's lesion. Gastrointest Endosc 2003 Aug;58(2):236-243.

https://doi.org/10.1067/mge.2003.328

6. Chaer RA, Helton WS. Dieulafoy's disease. J Am Coll Surg 2003 Feb;196(2):290-296. https://doi.org/10.1016/S1072-7515(02)01801-X

7. Teitelbaum EN, Hungness ES, Mahvi DM. Chapter 48: stomach. Townsend CM, Beauchamp DR, Evers MB, Mattox KL. Sabiston Textbook of Surgery. 20th ed. Elsevier. New York, NY 2016:1188-1236.

8. Saleh R, Lucerna A, Espinosa J, Scali V. Dieulafoy lesion: the little known sleeping giant of gastrointestinal bleeds. Am J Emerg Med 2016 Dec;34(12):2464.e3-2464.e5. https://doi.org/10.1016/j.ajem.2016.06.024

9. Nojkov B, Cappell MS. Gastrointestinal bleeding from Dieulafoy's lesion: clinical presentation, endoscopic findings, and endoscopic therapy. World J Gastrointest Endosc 2015;7(4):295-307.

https://doi.org/10.4253/wjge.v7.i4.295

10. Y1lmaz TU, Kozan R. Duodenal and jejunal Dieulafoy's lesions: optimal management. Clin exp gastroenterol 2017 Nov 7; 10:275-283.

https://doi.org/10.2147/CEG.S122784

11. Brandt LJ, Aroniadis OC. Chapter 37: vascular disorders of the gastrointestinal tract. Feldman M, Friedman LS, Brandt LJ. Sleisenger and Fordtran's Gastrointestinal and Liver Disease. 10th ed. Saunders/Elsevier. Philadelphia, PA;2016:617-635.

12. Kanth R, Mali P, Roy PK. Outcomes in Dieulafoy's lesion: a 10-year clinical review. Dig Dis Sci 2015 Jul;60(7):2097-2103. https://doi.org/10.1007/s10620-015-3568-1

13. Chung IK, Kim EJ, Lee MS, Kim HS, Park SH, Lee MH, Kim SJ, Cho MS. Bleeding Dieulafoy's lesions and the choice of endoscopic method: comparing the hemostatic efficacy of mechanical and injection methods. Gastrointest Endosc 2000 Dec;52(6):721-724.

https://doi.org/10.1067/mge.2000.108040

\section{CLINICAL CASE REPORT: DIEULAFOY'S LESION} I.Vilčinskaitė, G.Srèbaliūtè, M.Garčauskis

Keywords: upper gastrointestinal bleeding, Dieulafoy's lesion, angiography, anaemia, haemostasis.

Summary

Dieulafoy's lesion accounts for 1-2\% cases of upper gastrointestinal bleeding. Since the bleeding specific to this pathology is intermittent, the accurate diagnosis may sometimes require additional endoscopic evaluation or even angiography. The clinical case presented in this article is the cause of chronic anaemia which was found after the additional endoscopy. During the procedure of this endoscopy the state of active bleeding out of vascular defect in duodenum has been observed. Successful haemostasis was sustained combining medications with modern invasive haemostatic procedures. 